\title{
Magnetostratigraphy of the Oligocene Lower Krosno Beds from the Hulskie section (Outer Carpathians, Poland)
}

\author{
Jerzy NAWROCKI ${ }^{1, *}$, Tomasz MALATA² and Olga ROSOWIECKA ${ }^{1}$ \\ 1 Polish Geological Institute - National Research Institute, Rakowiecka 4, 00-975 Warszawa, Poland \\ 2 Polish Geological Institute - National Research Institute, Carpathian Branch, Skrzatów 1, 31-560 Kraków, Poland
}

Nawrocki, J., Malata, T., Rosowiecka, O., 2016. Magnetostratigraphy of the Oligocene Lower Krosno Beds from the Hulskie section (Outer Carpathians, Poland). Geological Quarterly, 60 (4): 935-942, doi: 10.7306/gq.1304

The Oligocene flysch sequence of the Lower Krosno Beds from the Hulskie section (Otryt Anticline) in the Polish Outer Carpathians was palaeomagnetically examined in order to check its usefulness for magnetostratigraphy. The flysch complex of the Lower Krosno Beds containing the Jasło and Zagórz limestone horizons revealed palaeomagnetic properties sufficient for a magnetostratigraphy to be established. Results of magnetostratigraphic correlation indicate that the Jasło limestone was deposited ca. 29.5 Ma (upper part of magnetic polarity chron C11). The age of the Zagórz limestone was defined as close to ca. 28.2 or $27.5 \mathrm{Ma}$ (upper parts of magnetic polarity chrons C10 or C11). The entire $450 \mathrm{~m}$ of the section was formed between ca. 30 and 27.7 or $26.3 \mathrm{Ma}$, depending on the assumed version of correlation to the global magnetic polarity scale. It implies an average sedimentary ratio of about 20 or $12 \mathrm{~cm}$ per thousand years. These values are significantly lower than those obtained for the Krosno Beds from a regional analysis of sediment deposition rate. The sedimentation of the Jasło and Zagórz limestone was most probably possible thanks to a slowdown of sedimentation rate in this part of the Krosno Beds. The palaeomagnetic directions from the Hulskie section do not display the Fisher-type distribution and do not fit the reversal test, and therefore cannot be used for any regional tectonic reconstruction.

Key words: Outer Western Carpathians, Krosno Beds, Jasło limestone, magnetostratigraphy.

\section{INTRODUCTION}

The Oligocene sequences of the Outer Carpathians in part described formally as the Krosno Beds contain intercalations of pelitic limestones. The most characteristic and widely distributed are the Jasło shales (Koszarski and Żytko, 1961), considered as isochronous within the whole area of their occurrence. Haczewski $(1984,1989)$ proposed the name "Jasło limestone" for the lower intercalation of limestones and the name "Zagórz limestone" for the younger limestone occurrence, and suggested a perfect continuity of fine laminae of the Jasło limestone over distances up to $240 \mathrm{~km}$ in the Silesian and Skole units (see also Ciurej and Haczewski, 2012). The planktonic foraminifera assemblage found in a close proximity of the Jasło limestone, and especialy the occurrence of species Turborotalia liverovskae (Bykowa) in assemblages from the lower horizon of the Jasło limestones, suggests the age of this strata close to the Rupelian and Chattian boundary (Olszewska, 1984). The age of the Jasło limestone should be linked with the base of the NP24 nannoplankton zone (see Kotlarczyk et al., 2006). Most of the results of

*Corresponding author, e-mail: jerzy.nawrocki@pgi.gov.pl

Received: November 5, 2015; accepted: July 7, 2016; first published online: July 15, 2016 palaeomagnetic investigations of the Magura and Silesian nappes of the Outer Carpathians in Poland point to the presence of their anticlockwise tectonic "en block" rotation of about $50^{\circ}$ during their Miocene emplacement (Marton et al., 2009). However, some data do not support such a significant rotation (Szaniawski et al., 2013). It should be stressed that palaeomagnetic samples from the Polish part of the Outer Carpathians, even those containing dual polarity directions, have not been documented so far in any long and continuous sections, i.e. in a way that is suitable for construction of magnetic polarity profiles.

The aim of this study was to develop a magnetostratigraphic scale for the Oligocene flysch sequence that contains intercalations of limestones with a significant potential for stratigraphic correlation on a super-regional scale. Good quality magnetostratigraphic data could provide more precise frames for chronostratigraphy of the Jasło and Zagórz limestones and could allow determining the sedimentation rate for that part of the Carpathian flysch. Moreover, we intended to check the applicability of obtained characteristic directions for tectonic reconstructions.

\section{SAMPLING SITE AND METHODS OF INVESTIGATION}

The Hulskie section (49 $\left.15^{\prime} 00^{\prime \prime} \mathrm{N} ; 2^{\circ} 32^{\prime} 06^{\prime \prime} \mathrm{E}\right)$ is located inside the southern limb of the Otryt Anticline. This structure con- 
sists of two Oligocene units - the Otryt Sandstone and the Supra-Otryt Beds (Fig. 1B). They form a part of the formal Carpathian lithostratigraphic unit - the Lower Krosno Beds (Jankowski et al., 2004; Malata and Jankowski, 2006). The flysch sequence is visible on the right bank of the San River near the ruins of the abandoned Hulskie village (Fig. 1A). An almost continuous outcrop extending along the river scarp consists of steeply inclined beds with their total thickness of about $450 \mathrm{~m}$. In the middle part of the section two horizons with limestone beds were recognized. The lower occurrence of carbonate rocks forming the Jasło limestone (Fig. 2) consists of 24 thin and laminated beds with a total thickness of about $43 \mathrm{~cm}$ dispersed in ca. $23 \mathrm{~m}$ of siliciclastic sediments. The Zagórz limestone consists of 14 thin beds with a total thickness of about $15 \mathrm{~cm}$ dispersed in $>3 \mathrm{~m}$ of mudstones. The thickness of rocks separating the Jasło and Zagórze limestones of the Hulskie section is ca. $120 \mathrm{~m}$ being the largest in the whole Polish Outer Carpathians.

A total of twenty hand samples for palaeomagnetic studies were collected from the Hulskie section. Most of them were taken from mudstones (10) and sandstones (7). The limestone beds were sampled at three sites only. Up to five specimens were cut from each sample. The natural remanent magnetization (NRM) of the specimens was measured using a JR-6A spinner magnetometer with a noise level of about $0.3 \times$ $10^{-5} \mathrm{~A} / \mathrm{m}$. After each thermal demagnetization step the magnetic susceptibility signal was monitored. Thirty-two specimens that do not reveal a substantial increase of magnetic susceptibility at temperatures of about $300^{\circ} \mathrm{C}$ have been subjected to stepwise thermal demagnetization conducted in a $\mu$-metal shielded oven, which reduces the ambient magnetic field close to a few nT. The rest of specimens (28) with such a rapid increase of magnetic susceptibility were demagnetized thermally up to $250^{\circ} \mathrm{C}$ and have subsequently been subjected to a stepwise alternating field demagnetization. Least-square line fit methods, as presented by Kirschvink (1980), were used to calculate the components of the characteristic remanence and their unblocking temperature spectra. Magnetic mineralogy was determined from isothermal remanent magnetization (IRM) techniques and thermomagnetic analyses (Lowrie, 1990). Anisotropy of magnetic susceptibility (AMS) was measured on a $K L Y-2$ susceptibility bridge and the resulting AMS fabrics were computed using the ANISO program (Jelinek, 1977).

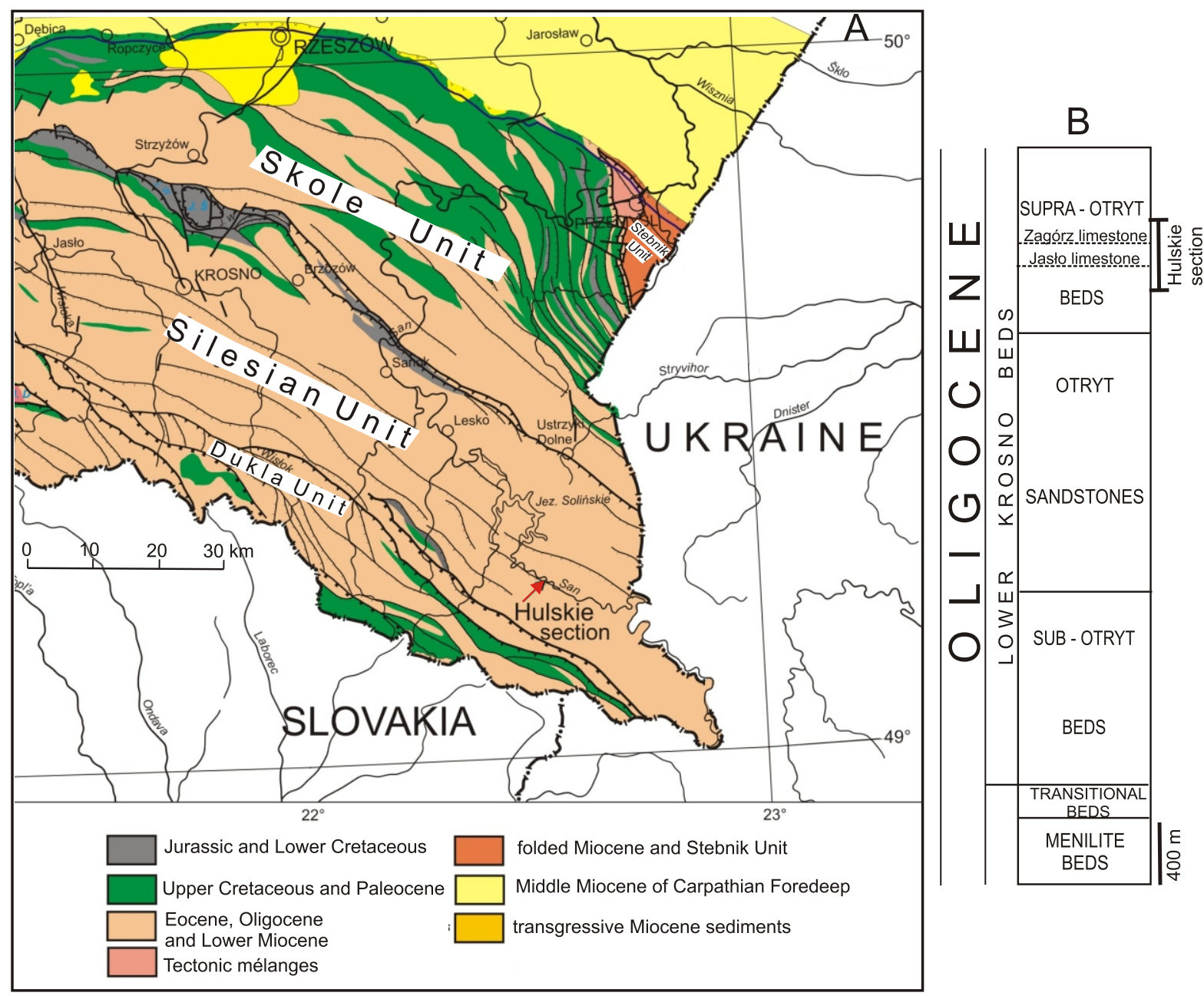

Fig. 1A - geological sketch map of the eastern part of the Western Outer Carpathians in Poland (after Jankowski et al., 2004) with the Hulskie section marked by arrow; B - location of the Hulskie section on the background of simplified lithostratigraphic chart 


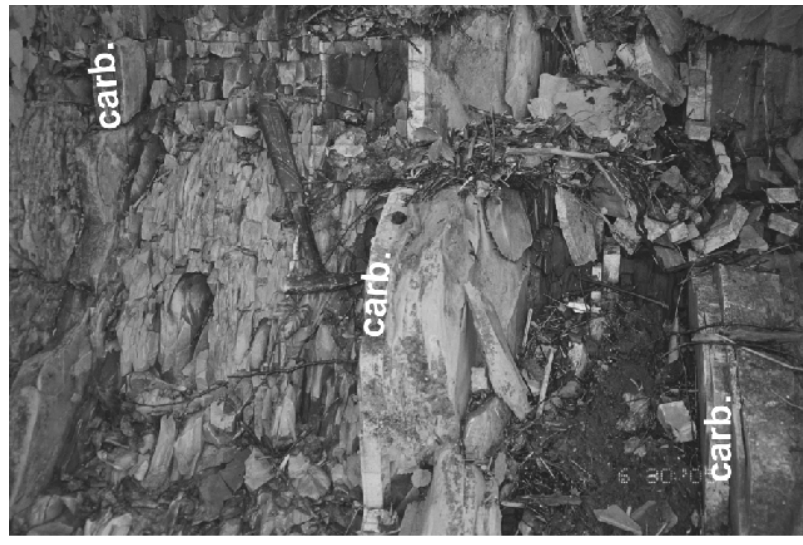

Fig. 2. Carbonate beds (carb.) of the Jasło limestone in the Hulskie section

\section{RESULTS}

\section{MAGNETIC CARRIERS AND ANISOTROPY OF MAGNETIC SUSCEPTIBILITY}

The IRM diagrams indicate that low to medium coercivity magnetic carriers are predominant in the studied rocks. More than $90 \%$ of IRM has been acquired in the field as low as $200 \mathrm{mT}$ (Fig. 3). Two significant drops of the IRM intensity can be observed in the thermomagnetic curves obtained for soft and medium coercivity components (Fig. 4). The first one can be noted at temperatures of ca. $300^{\circ} \mathrm{C}$ and the second one corresponds to a temperature close to $400^{\circ} \mathrm{C}$. Such thermomagnetic parameters point to the presence of ferric sulphides (greigite or pyrrhotite; see e.g., Dekkers, 1989; Roberts et al., 2011) and maghemite- or/and titanium-rich magnetite (see e.g., Dunlop and Özdemir, 1997) in all examined samples. The occurrence of ferric sulphides is unexpected because the rocks

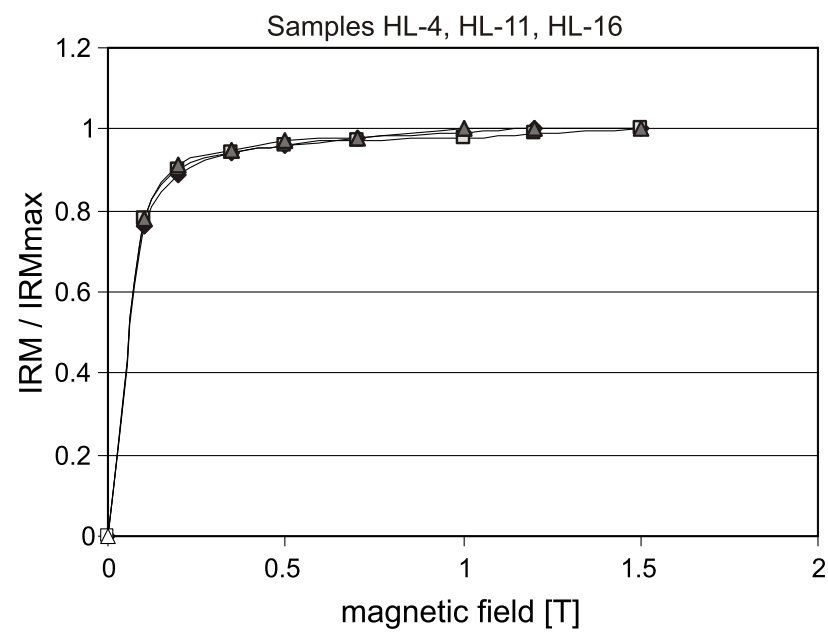

Fig. 3. Isothermal remanence acquisition curves prepared for three samples from the Hulskie section

IRM - isothermal remanence acquired in the field given; IRMmax - maximum value of isothermal remanence
Sample HL-4

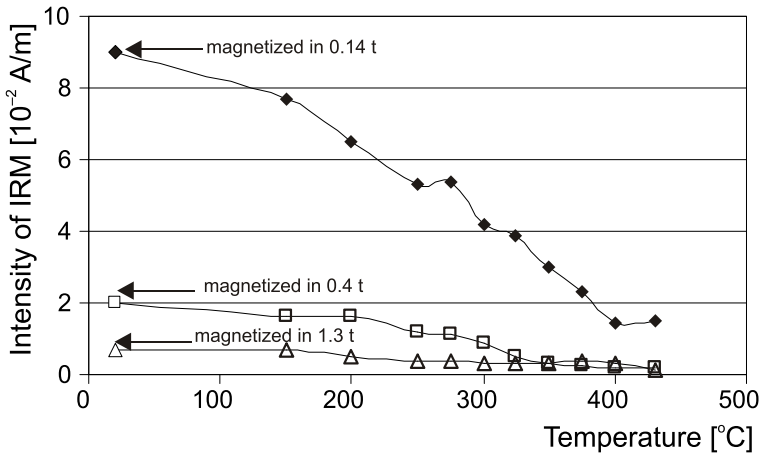

Sample HL-11

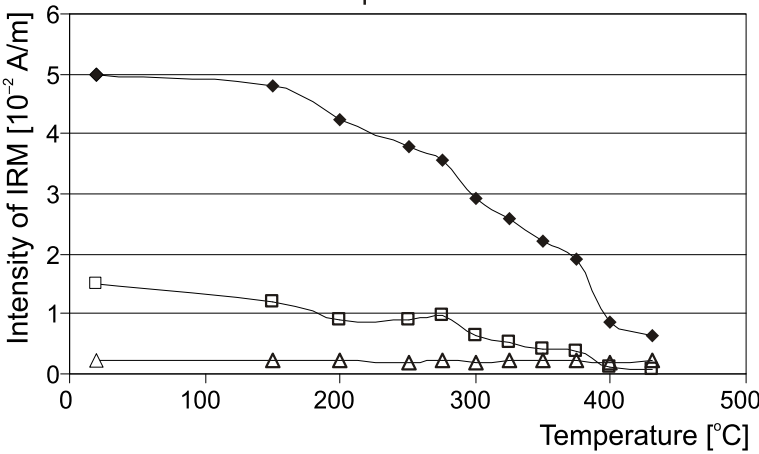

Sample HL-16

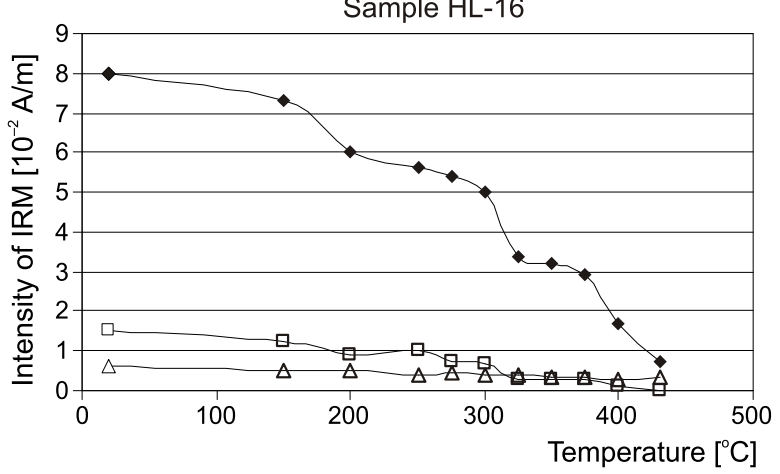

Fig. 4. Thermal demagnetization of orthogonal-axes IRM curves (Lowrie, 1990) obtained for three samples from the Hulskie section

For location of studied samples see Figure 8

reached the magnetite window during their deep burial (Hurai et al., 2006; Aubourg et al., 2012).

Results of the anisotropy of magnetic susceptibility measurements revealed the presence of well-grouped vertical minimum susceptibility axes and almost horizontal maximum axes that are perpendicular to the dip direction (Fig. 5). The degree of anisotropy is not higher than $6.8 \%$ with a mean value of $3.9 \%$. The measured lineation does not exceed $1.2 \%$ with a mean value of $0.56 \%$. The foliation parameter is as high as $6.5 \%$ with a mean value of $3.3 \%$. The values of volume magnetic susceptibility were enclosed between $12 \times 10^{-6} \mathrm{SI}$ units (carbonate rocks) and $273 \times 10^{-6} \mathrm{SI}$ units (mudstones).

\section{CHARACTERISTIC COMPONENTS AND MAGNETOSTRATIGRAPHY}

Samples taken from the Jasło limestone and two samples from sandstones revealed the presence of very unstable 


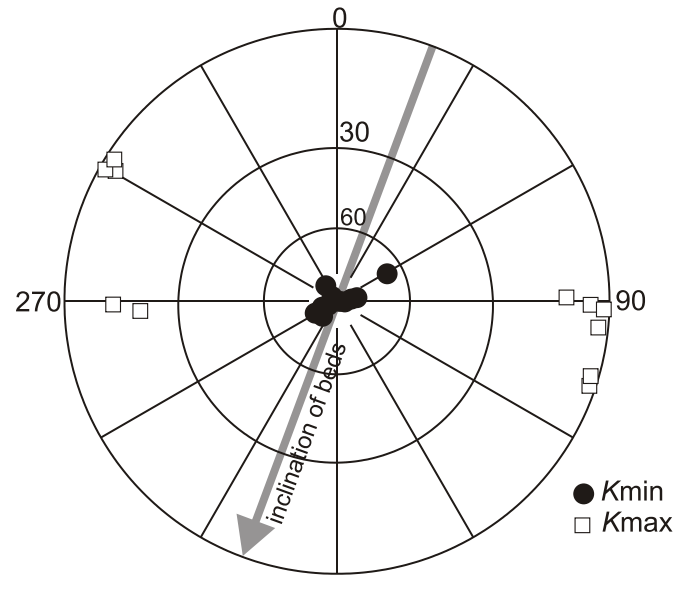

Fig. 5. The anisotropy of magnetic susceptibility stereoplot with the distribution of principal susceptibility axes defined for eleven specimens from the Hulskie section

Maximum degree of anisotropy is $6.8 \%$; its mean value is as high as $3.3 \%$ palaeomagnetic directions. Fortunately, the rest of samples contained two distinct components with medium to steep positive or negative inclinations and NW or SE declination, respectively (Fig. 6). They were demagnetized with alternating fields of amplitude $40-70 \mathrm{mT}$ or at temperatures of ca. $375^{\circ}$. However, their real maximum unblocking temperatures are most probably slightly higher. They cannot be unambiguously defined because of substantial increase of magnetic susceptibility at demagnetizing temperatures above $400^{\circ} \mathrm{C}$ most probably due to oxidation of ferric sulphides to magnetite. In two specimens the characteristic component was preserved at temperatures as high as $430^{\circ} \mathrm{C}$.

After tectonic correction the normal polarity characteristic directions with positive inclinations are confined to the NW quarter of the hemisphere, but their mean has a low precision parameter $K$ (Fig. 7). Most of the reversed polarity directions with negative inclinations after tectonic corrections are grouped in the opposite, SE quarter of the hemisphere. The mean reversed direction has a poor precision parameter $K$ as well. It is not exactly opposite to the normal polarity mean direction. With a calculated critical angle $\gamma_{c}=14.4$ and an observed angle $\gamma=28.1$ they evidently do not pass the reversal test (McFadden
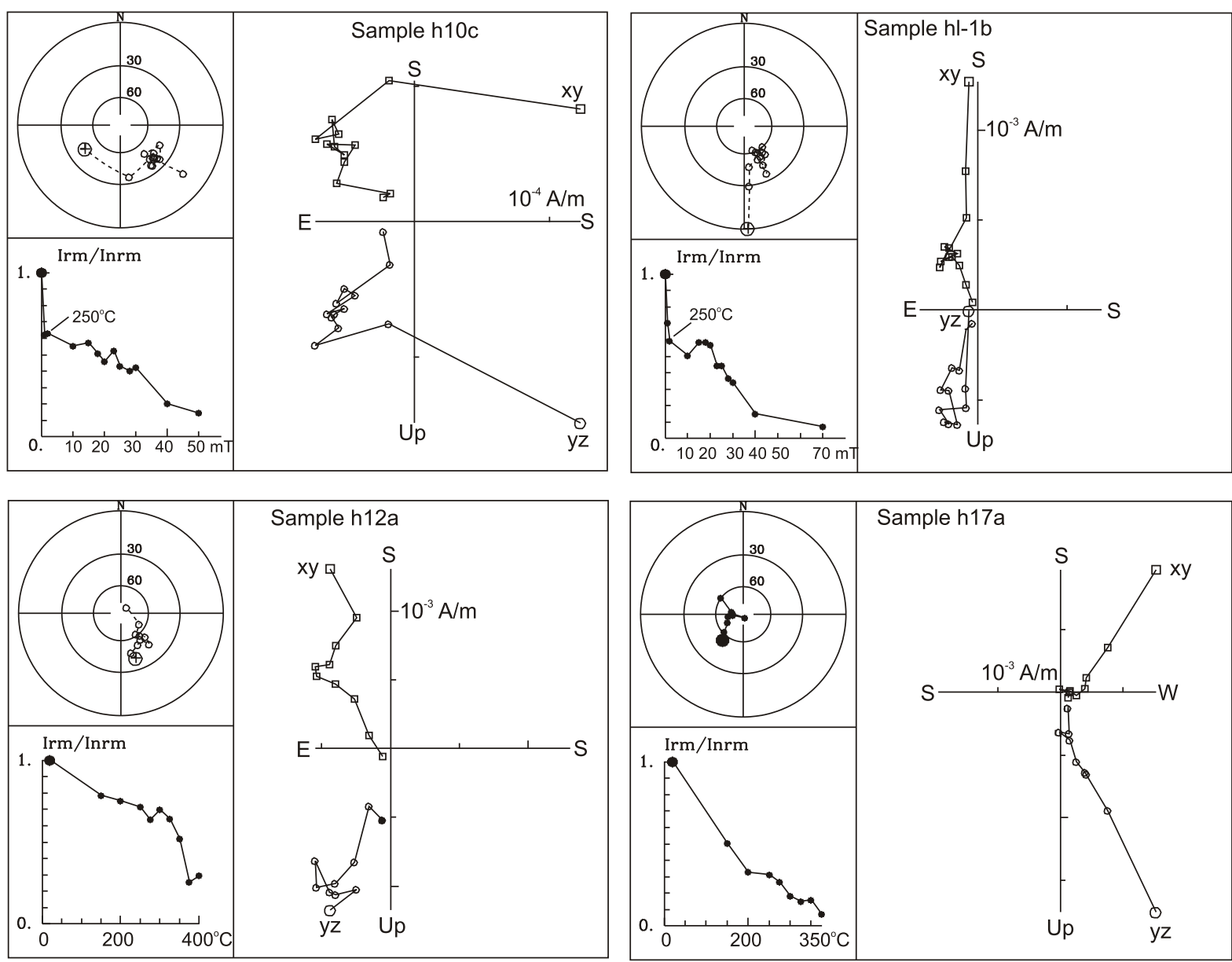

Fig. 6. Typical demagnetization characteristics (demagnetization paths, intensity decay curves and orthogonal plots) of flysch samples from the Hulskie section

Circles in the orthogonal plots represent vertical projections, squares represent horizontal projections; Irm - intensity of remanent magnetization, Inrm - initial intensity of natural remanent magnetization; the diagrams were prepared using a computer package developed by Lewandowski et al. (1997) 


\section{HULSKIE - NORMAL POLARITY SPECIMENS} (before tectonic correction)

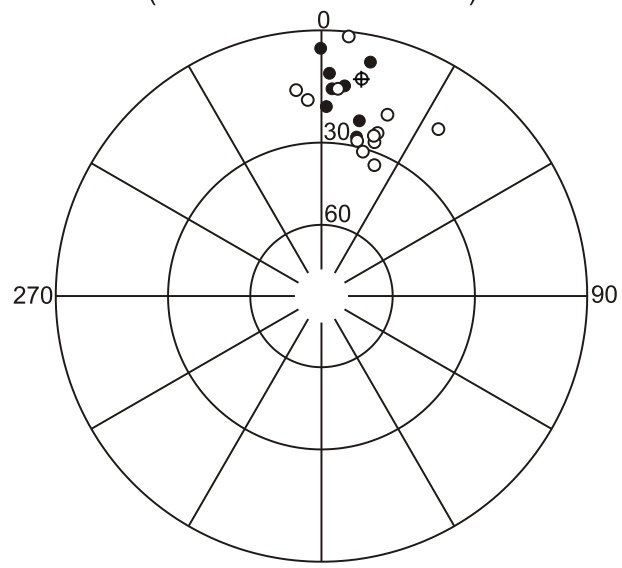

$\alpha=9.3, K=13.1, N=20, D=10, I=-7, L=-37, F=9$

HULSKIE - NORMAL POLARITY SPECIMENS (after tectonic correction)

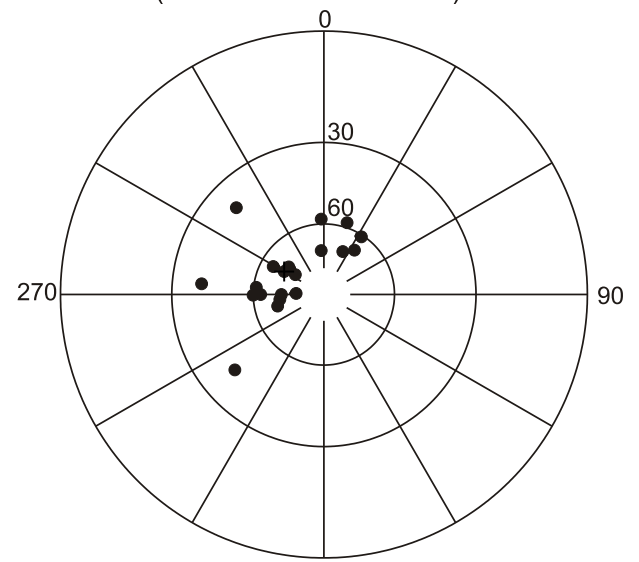

$\alpha=9.7, K=12.3, N=20, D=301, I=72, L=55, F=327$
HULSKIE - REVERSED POLARITY SPECIMENS (before tectonic correction)

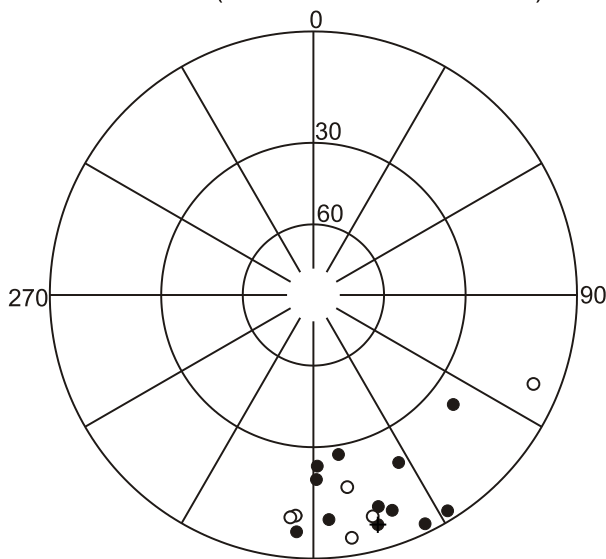

$\alpha=11.0, K=11.5, N=17, D=164, I=6, L=-36, F=42$

HULSKIE - REVERSED POLARITY SPECIMENS (after tectonic correction)

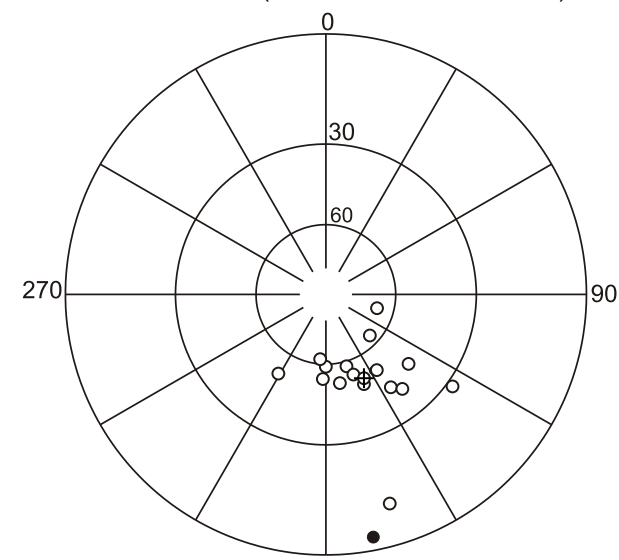

$\alpha=11.2, K=11.1, N=17, D=157, I=-49, L=64, F=252$

HULSKIE - ALL SAMPLES RECALCULATED TO NORMAL POLARITY (after tectonic correction)

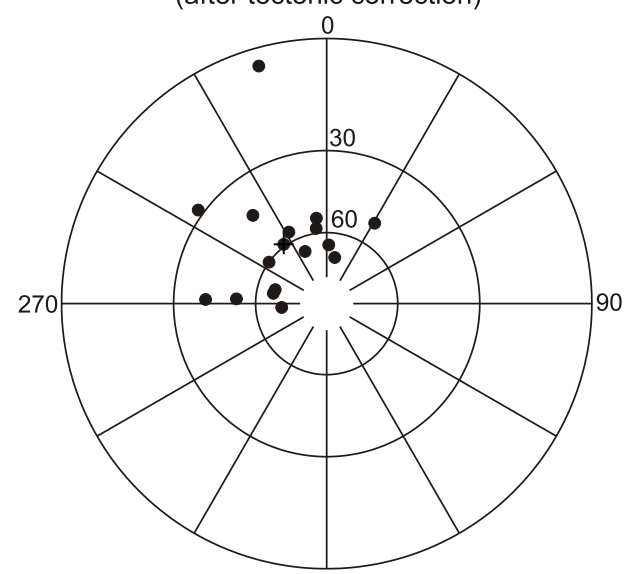

$\alpha=12.0, K=9.1, N=16, D=322, I=59, L=62, F=287$

Fig. 7. Stereographic plots with palaeomagnetic line-fit directions at specimen and sample levels obtained for the Hulskie section

$\alpha$ - semi-angle of the cone of $95 \%$ confidence, $K$ - precision parameter (after Fisher, 1953), $N$ - number of specimens/samples, $D$ - declination, $I$ - inclination, $L$ - latitude of palaeomagnetic pole,

$F$ - longitude of palaeomagnetic pole 
and McElhinny, 1990). The characteristic directions in the present-day coordinates, i.e. before tectonic correction, have similar statistics parameters $K$ and $\alpha$ as they have after tectonic restoration (Fig. 7). However, their shallow inclination implies an equatorial position of the Hulskie section in the Late Oligocene. Such a location is impossible because of the well-known general palaeogeographic frames of the study area. This part of the Carpathians was situated in moderate palaeolatitudes at that time (see e.g., Golonka, 2002).

Despite the substantial scatter of the normal and reversed polarity directions they are grouped sequentially in the normal and reversed polarity zones. Three reversed and two normal polarity zones were distinguished in the Hulskie section (Fig. 8). Because of a very unstable palaeomagnetic record in the Jasło limestone and slightly below it, no polarity has been assigned for this part of the section.

\section{DISCUSSION}

The magnetic carriers in the studied rocks have a very complex nature. The presence of ferric sulphides and probably maghemite can point to an at least partly diagenetic origin of the characteristic remanent magnetization components. However, the record of consistent and quite frequent magnetic polarity zones may suggest that magnetic remanence was not significantly delayed. In fact, greigite can record early diagenetic magnetic remanence because it can grow rapidly in the water column of euxinic marine waters (Cutter and Kluckhohn, 1999), or in anoxic natural sediments within decades or less after deposition (Reynolds et al., 1999). In contrast, however, it has been demonstrated that greigite can grow also during later diagenesis, which can lead to delayed acquisition of natural remanent magnetization (e.g., Roberts and Weaver, 2005). An- other ferric sulphide, pyrrhotite could be formed during the deep burial of the studied rocks, but they most probably have never reached the required depth of at least $6 \mathrm{~km}$ (Hurai et al., 2006). The magnetic fabrics are distinctly adjusted giving a quite strong magnetic foliation with well-grouped vertical axes after tectonic tilt correction. A primary and/or early diagenetic magnetic structure of the rocks has not been destroyed by the late diagenetic magnetic minerals.

The biostratigraphy allows correlating the Jasło limestone with the bottom part of nannoplankton zone NP24 (see Kotlarczyk et al., 2006). The Zagórz limestone is also linked with the same nannoplankton zone (Bak, 1999). The polarity pattern obtained for the Hulskie section fits to the reference polarity scale for this part of the Oligocene, but because of insufficient density of sampling and possible gaps in the magnetostratigraphic record, two versions of correlation are presented (Fig. 8). Both of them are in agreement with biostratigraphic data. According to the correlation of the local-to-global magnetic polarity scale, the Jasło limestone was deposited ca. $29.5 \mathrm{Ma}$ (upper part of magnetic polarity chron C11). The age of the Zagórz limestone was defined as close to ca. 28.2 or 27.5 Ma (upper part of the magnetic polarity chrons C10 or C11). The entire $450 \mathrm{~m}$ of studied section was formed between ca. 30 and 27.7 or $26.3 \mathrm{Ma}$, depending on the assumed version of correlation. It implies an average sedimentary ratio of about 20 or $12 \mathrm{~cm}$ per thousand years. These values are significantly lower than those obtained for the Krosno Beds from a regional analysis of sediment deposition rate $(35-90 \mathrm{~cm}$ per thousand years; Poprawa et al., 2006). It cannot be excluded that the sedimentation of the Jasło and Zagórz limestone was possible thanks to a slowdown of sedimentation rate in this part of the Krosno Beds.

A tectonic interpretation of the characteristic palaeomagnetic directions from the Hulskie section seems to be impossible. The mean direction is rotated counterclockwise from the north by
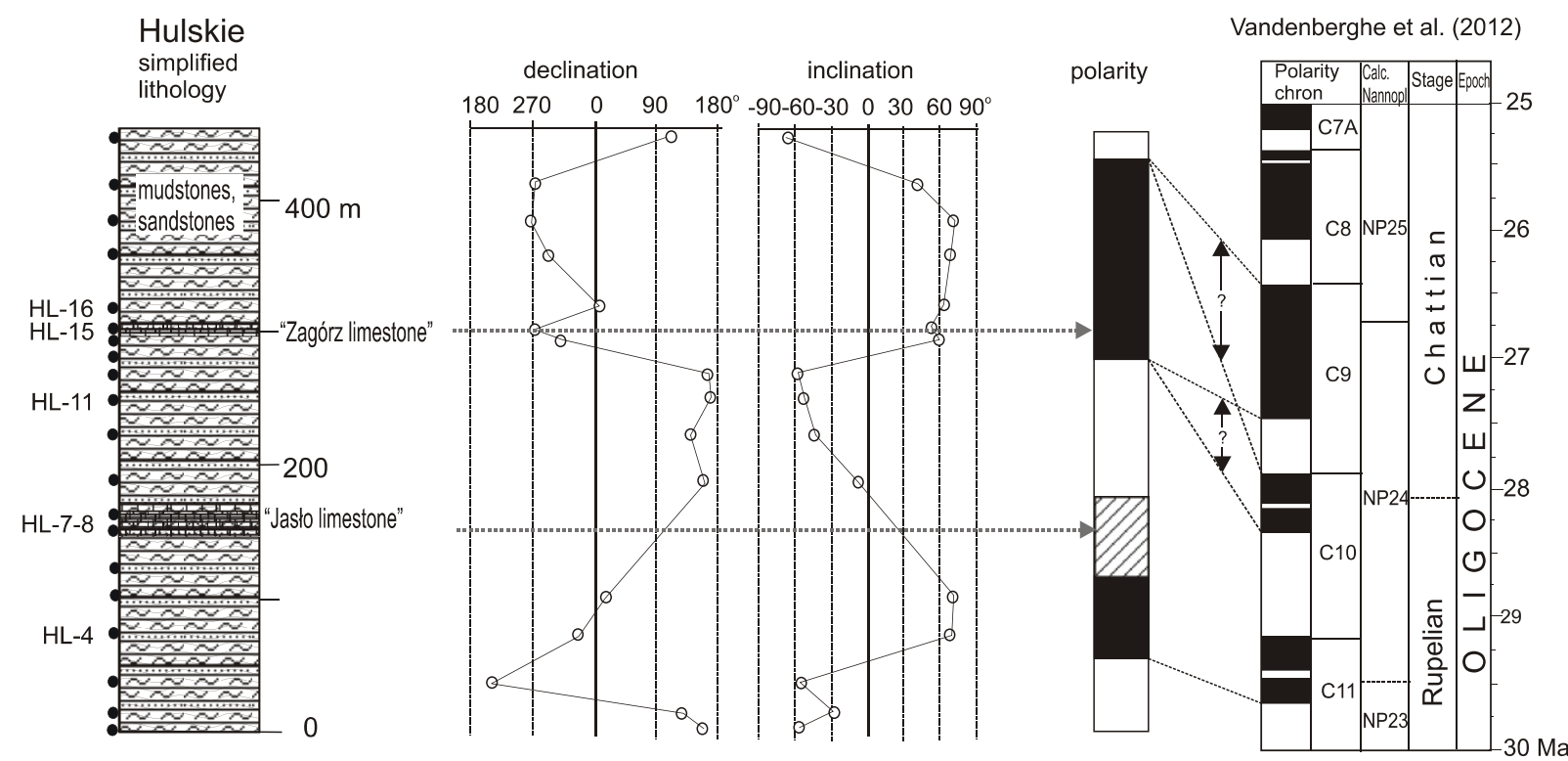

HL-15 • sampling sities reversed polarity normal polarity

uncertain polarity

Fig. 8. Changes of declination, inclination and magnetic polarities in the Hulskie section 
about $40^{\circ}$, supporting the earlier result of counterclockwise tectonic rotation of the Outer Carpathians in Poland of about $50^{\circ}$ during the Miocene uplift as suggested by Marton et al. (2009). On the other hand, however, the directions on the sample or specimen level do not display a Fisherian distribution (Fisher, 1953). The precision parameter $K$ is very low being between 9.1 and 12.3 on the different statistics levels (Fig. 7). The mean directions calculated for the normal $\left(D=301^{\circ}, I=72^{\circ}\right)$ and reversed $\left(D=157^{\circ}, I=-49^{\circ}\right)$ polarity specimens are not antipodal and do not pass the reversal test. The characteristic directions are most probably still of complex (overlapping) nature having an unremoved overprint. They could contain an admixture of secondary components of both polarities. From these reasons the palaeomagnetic directions from the Hulskie section cannot be reliably used for any tectonic reconstructions. Fortunately, these rocks are suitable for construction of the local magnetic polarity scale. Perhaps, a combined bio- and magnetostratigraphic record could improve the resolution of the existing chronostratigraphic frames in the Outer Carpathians.

\section{CONCLUSIONS}

The Oligocene flysch sequence of the Lower Krosno Beds from the Hulskie section that contains the Jasło and Zagórz limestones has revealed palaeomagnetic properties that are sufficient for magnetostratigraphic studies. A correlation of the local polarity pattern and the global magnetic polarity time scale indicates that the Jasło limestone was deposited ca. 29.5 Ma. The age of the Zagórz limestone was defined as close to ca. 28.2 or $27.5 \mathrm{Ma}$. The entire $450 \mathrm{~m}$ long section was formed between ca. 30 and 27.7 or $26.3 \mathrm{Ma}$, depending on the assumed version of correlation. It implies an average sedimentary ratio of about 20 or $12 \mathrm{~cm}$ per thousand years. These values are significantly lower than those obtained for the Krosno Beds from a regional analysis of sediment deposition rate. It cannot be excluded that the sedimentation of the Jasło and Zagórz limestone was linked with a slowdown of sedimentation rate in this part of the Krosno Beds.

The palaeomagnetic directions from the Hulskie section do not display a Fisher-type distribution and cannot be used for any regional or global tectonic reconstruction. They still contain overlapping secondary components.

Acknowledgements. We thank C. Langereis for critical evaluation of the manuscript with many constructive remarks and improvement of English. R. Szaniawski and an anonymous reviewer are also warmly acknowledged for helpful suggestions. This work was partly supported by the Polish National Fund of Environmental Protection and Water Management.

\section{REFERENCES}

Aubourg, Ch., Pozzi, J.P., Kars, M., 2012. Burial, claystones remagnetization and some consequences for magnetostratigraphy. Geological Society Special Publications, 371: 181-188.

Bąk, K., 1999. Late Oligocene foraminifera from the Krosno Beds in the San Valley section (Bieszczady Mountains); Silesian Unit, Polish Outer Carpathians. Annales Societatis Geologorum Poloniae, 69: 195-217.

Ciurej, A., Haczewski, G., 2012. The Tylawa Limestones - a regional marker horizon in the Lower Oligocene of the Paratethys: diagnostic characteristic from the type area. Geological Quarterly, 56 (4): 833-844.

Cutter, G.A., Kluckhohn, R.S., 1999. The cycling of particulate carbon, nitrogen, sulfur, and sulfur species (iron monosulfide, greigite, pyrite, and organic sulfur) in the water columns of Framvaren Fjord and the Black Sea. Marine Chemistry, 67: 149-160.

Dekkers, M.J., 1989. Magnetic properties of natural pyrrhotite. II. High and low-temperature behaviour of Jrs and TRM as function of grain size. Physics of the Earth and Planetetary Interiors, 57: 266-283.

Dunlop, D.J., Özdemir, Ö., 1997. Rock Magnetism Fundamentals and Frontiers. Cambridge University Press, New York, London and Cambridge.

Fisher, R.A., 1953. Dispersion on a sphere. Proceedings of the Royal Society, London, A 217: 295-305.

Golonka, J., 2002. Plate-tectonic maps of the Phanerozoic. SEPM Special Publication, 72: 21-75.

Haczewski, G., 1984. Correlation of laminae in chronohorizons of Jasło limestone and Zagórz limestone (Outer Carpathians) (in Polish with English summary). Geological Quarterly, 28 (3/4): 675-688.

Haczewski, G., 1989. Coccolith limestone horizons in the Menilite-Krosno series (Oligocene, Carpathians) - identification, correlation and origin (in Polish with English summary). Annales Societatis Geologorum Poloniae, 59: 435-523.
Hurai, V., Marko, F., Tokarski, A.K., Świerczewska, A., Kotulová, J., Biroň, A., 2006. Fluid inclusion evidence for deep burial of the Tertiary accretionary wedge of the Carpathians. Terra Nova, 18: 440-446.

Jankowski, L., Kopciowski, R., Ryłko, W., eds., 2004. Geological Map of the Outer Carpathians: Borderlands of Poland, Ukraine and Slovakia 1:200 000. PIG, Warszawa

Jelinek, V., 1977. The Statistical Theory of Measuring Anisotropy of Magnetic Susceptibility of Rocks and its Application. Brno, Geofyzika: 1-88.

Kirschvink, J.L., 1980. The least square line and plane and the analysis of paleomagnetic data. Geophysical Journal of the Royal Astronomical Society, 62: 699-718.

Koszarski, L., Żytko, K., 1961. Jasło shales within the Menilite-Krosno series in the Middle Carpathians (in Polish with English summary). Biuletyn Instytutu Geologicznego, 116: 87-214.

Kotlarczyk, J., Jerzmańska, A., Świdnicka, E., Wiszniowska, T., 2006. A framework of ichthyofaunal ecostratigraphy of the Oligocene-Early Miocene strata of the Polish Outer Carpathian Basin. Annales Societatis Geologorum Poloniae, 76: 1-111.

Lewandowski, M., Werner, T., Nowożyński, K., 1997. PCA - a package of Fortran programs for paleomagnetic data analysis. Institute of Geophysics. Polish Academy of Sciences, manuscript.

Lowrie, W., 1990. Identification of ferromagnetic minerals in a rock by coercivity and unblocking temperature properties. Geophysical Research Letters, 17: 159-162.

Malata, T., Jankowski, L., 2006. Szczegółowa mapa geologiczna Polski w skali 1:50 000, arkusz Lutowiska (1066) (in Polish). PIG, NAG, Nr. 913426, Warszawa.

Marton, E., Rauch-Włodarska, M., Krejči, O., Tokarski, A.K. Bubik, M., 2009. An integrated palaeomagnetic and MS study of the Tertiary flysch from the Outer Western Carpathians. Geophysical Journal International, 177: 925-940. 
McFadden, P.L., McElhinny, M.W., 1990. Classification of the reversal test in palaeomagnetism. Geophysical Journal International, 103: 725-729.

Olszewska, B., 1984. Some remarks on accompanying foraminifer assemblages in Jasło limestones in the Polish Outer Carpathians (in Polish with English summary). Geological Quarterly, 28 (3/4): 689-700.

Poprawa, P., Malata, T., Oszczypko, N., Słomka, T., Golonka, J., Krobicki, M., 2006. Tectonic activity of sediment source areas for the Western Outer Carpathian basin - constraints from analysis of sediment deposition rate (in Polish with English summary). Przegląd Geologiczny, 54: 878-887.

Reynolds, R.L., Rosenbaum, J.G., van Metre, P., Tuttle, M., Callender, E., Goldin, A., 1999. Greigite as an indicator of drought - The 1912-1994 sediment magnetic record from White
Rock Lake, Dallas, Texas, USA. Journal of Paleolimnology, 21: 193-206.

Roberts, A.P., Weaver, R., 2005. Multiple mechanisms of remagnetization involving sedimentary greigite $\left(\mathrm{Fe}_{3} \mathrm{~S}_{4}\right)$. Earth and Planetary Science Letters, 231: 263-277.

Roberts, A.P., Chang, L., Rowan, C.J., Horng, C-S., Florindo, F. 2011. Magnetic properties of sedimentary greigite $\left(\mathrm{Fe}_{3} \mathrm{~S}_{4}\right)$ : an update. Review of Geophysics, 49: 1-46.

Szaniawski, R., Mazzoli, S., Jankowski, L., Zattin, M., 2013. No large-magnitude tectonic rotations of the Subsilesian Unit of the Outer Western Carpathians: evidence from primary magnetization recorded in hematite-bearing Węglówka Marls (Senonian to Eocene). Journal of Geodynamics, 71: 14-24.

Vandenberghe, N., Hilgen, F.J., Speijer, R.P., 2012. The Paleogene Period. In: The Geologic Time Scale 2012 (eds. F.M. Gradstein, J.G. Ogg, M. Schmitz and G. Ogg): 855-921. Elsevier B.V. 